\title{
Anti-melanogenic effect of Eruca sativa extract
}

\author{
Hyun-Soo Kim* \\ Department of Food Science and Technology, Jungwon University, Goesan 28024, Korea
}

\section{루꼴라(Eruca sativa) 추출물의 멜라닌 생성 저해 효과}

\author{
김현수* \\ 중원대학교 식품공학과
}

\begin{abstract}
Eruca sativa (known as rocket plant) is a member of the Brassicaceae, which is considered an important chemo-preventive plant family. Although Eruca sativa has positive biological effects such as antioxidant and renal protective activities, the effect of the Eruca sativa extract as a therapeutic agent for skin whitening has not been reported. In this study, we investigated the applicability of the extract of Eruca sativa as a functional materials by examining the its physiological activities. The Eruca sativa extract showed low cytotoxicity against murine melanoma B16F10 cells. At concentrations (below $100 \mathrm{mg} / \mathrm{L}$ ) that showed none or little cytotoxicity, the Eruca sativa extract showed high DPPH radical scavenging activity (ID50, $17.60 \mathrm{mg} / \mathrm{L}$ ). In addition, the Eruca sativa extract inhibited tyrosinase activity $\left(\right.$ ID $_{50}, 132.54 \mathrm{mg} / \mathrm{L}$ ) and decreased melanin content $\left(\right.$ ID $_{50}, 158.90 \mathrm{mg} / \mathrm{L}$ ). Finally, the treatment with the Eruca sativa extract suppressed the protein expression of tyrosinase in a concentration-dependent manner. These findings suggested that the Eruca sativa extract inhibited melanin synthesis by not only suppressing intracellular tyrosinase expression but also directly inhibiting tyrosinase activity. Therefore, these results indicate that the Eruca sativa extract may be an effective material for functional cosmetics such as skin whitening materials.
\end{abstract}

Key words : Eruca sativa, melanin, tyrosinase

\section{서 론}

현대사회에서 증가하는 건조 환경 및 사회적 스트레스 등으로 악화되고 있는 피부장벽손상(건조피부, 민감성피 부, 노인성 건성피부, 아토피피부)을 개선하기 위한 천연소 재 개발에 대한 연구가 많이 진행되고 있으며 특히, 흰색 피부를 선호하는 여성들을 중심으로 미백효과를 볼 수 있는 소재개발에 대한 관심이 증가하고 있다(1). 피부색은 멜라 닌 생성세포가 합성하는 멜라닌(melanin)의 양과 종류에 따라 결정되며 자외선과 같은 외부자극으로부터 피부를 보호하기 위해 멜라닌 생성을 하게 된다. 그러나 피부표면

*Corresponding author. E-mail : hyun1006@jwu.ac.kr Phone : 82-43-830-8616, Fax : 82-43-830-8679

Received 2 October 2015; Revised 29 October 2015; Accepted 11 December 2015.

Copyright (c) The Korean Society of Food Preservation. All rights reserved.
에 과도한 멜라닌 합성과 축적은 기미, 주근깨와 같은 과 색소 침착 증상이 나타나게 된다(2). 멜라닌 생성은 tyrosinase, tyrosinase related protein-1(TRP-1), TRP-2 효소 에 의해 조절되며 tyrosinase는 구리를 포함한 효소로서 멜 라닌 형성에 중요한 역할을 하고 있다(3). Tyrosinase는 멜라 노좀(melanosome)내에서 tyrosine을 산화시켜 DOPA를 생 성하는 tyrosine hydroxylase로서, 또한, DOPA를 산화시켜 DOPA quinone을 만드는 DOPA oxidase로서 작용하여 멜라 닌 중합체를 합성하는 핵심 효소로 작용한다(3). 따라서 멜라닌 생합성을 억제하여 미백효과를 가져올 수 있는 독성 이 없는 천연소재 물질에 대한 개발이 요구되고 있다(4).

본 연구의 재료인 Eruca sativa 는 루꼴라(rucola)로 불리 우며 피자같은 이탈리아 요리에 많이 쓰이는 채소로 프랑스 어로 로켓(rocket), 영어로는 아루굴라(arugula)라고 하는데, 로켓은 프랑스어인 로케트(roquette)에서 유래한다. 고대 로 마에서 루꼴라의 잎과 씨를 소중히 여겼으며 씨는 기름에 향을 내는데 사용하였으며 잎과 꽃, 씨앗을 모두 식용하는 
데 맛이 고소하고 쌉싸름하고 머스터드와 같이 톡 쏘는 매운 향이 있는 것이 특징이고 비타민 $\mathrm{C}$, 칼륨의 함유량이 풍부하여 건강식, 미용채소로도 많이 알려져 있다(5). 특히, 잎은 잘 빻아서 상처난 곳, 아픈 관절, 뼈가 부러진 곳에 치료 목적으로도 사용되었다고 전해진다. 고대문헌에 보면 전갈 독 치료, 체내 기생충제거, 얼굴피부의 spot제거, 식초 와 함께 얼굴 잡티 제거, 흉터/멍 축소, 루꼴라 샐러드를 다져서 눈에 바르면 시력회복 등 혈액순환을 도와 몸을 덥게 하고 에너지를 충전시키며 이뇨와 소화를 돕는다는 보고(6)가 있는 등 예로부터 많은 효능이 있으며 이에 활용 을 하고 있음을 보여준다. 이와 같이 루꼴라(Eruca sativa)는 다양한 생리활성에 따른 기능성 소재 응용가능성을 기대할 수 있음에도 불구하고 과학적으로 활성기작 및 메카니즘에 대한 연구가 부족하며 특히, 미백활성 등 피부개선 효과를 비롯한 기능성 화장품소재에 활용하기 위한 연구는 미흡한 실정이다. 따라서 본 연구에서는 루꼴라 잎 추출시료를 가 지고 항산화 및 안전성 시험을 비롯한 생리활성 시험과 미백시험을 비롯한 피부효능 개선 시험을 조사하여 기능성 화장품 소재로서의 개발 가능성을 검토하고자 하였다.

\section{재료 및 방법}

\section{실험재료}

루꼴라(E sativa) 잎은 가락동 농수산물 시장에서 구입하 여 사용하였다. 시료 30 40 g에 에탄올 $200 \mathrm{~mL}$ 를 첨가하고 용매추출장치(ASE300 Accelerated Solvent Extractor, Dionex Corporation, Waltham, MA, USA)를 이용하여 $50^{\circ} \mathrm{C}$, $1,500 \mathrm{psi}$ 에서 20분 동안 추출하였다. 이후 건조기(Modul spin 40, Biotron Corporation, Calgary, Alberta, Canada)에서 $40^{\circ} \mathrm{C}$ 에서 24 시간 동안 건조하고 실험에 사용하였다.

\section{세포독성평가}

세포독성 시험은 세포내의 미토콘드리아 탈수소효소에 의해 water soluble tetrazolium salts(WST-1)에서 불용성의 formazan결정으로 변환되는 원리를 이용한다(7). Formazan 이 많이 생성될수록 세포 활성이 커지는 것을 의미한다. Formazan은 dimethly sulfoxide에 녹아서 보라색 빛을 띄는 데 spectrophotometer로 $540 \mathrm{~nm}$ 파장에서 $\mathrm{OD}$ 값을 재어서 정량한다. 미국 세포주은행(ATCC)에서 분양 받은 멜라노 마 세포(murine melanoma $\mathrm{B} 16 \mathrm{~F} 10$ )를 $10 \%$ 우태아 혈청 (fetal bovine serum: FBS, Gibco, Waltham, MA, USA)이 포함된 Dulbecco's Modified Eagle's medium(DMEM)에서 배양하고 24 well plate에 $2 \times 10^{4}$ cells/well 의 농도로 세포를 접종한 후, $37^{\circ} \mathrm{C}, 5 \% \mathrm{CO}_{2}$ 조건에서 배양한다. 이후 배양세 포에 추출물을 농도별로 처리하고 72 시간 배양하였다. 결 과는 $\%$ 로 환산하였다. 각 처리농도에서의 결과 수치로 $50 \%$
저해 농도 $\left(\mathrm{ID}_{50}\right)$ 을 계산하여 세포 독성 정도를 표현하였다.

\section{항산화력 측정}

DPPH radical 소거능 실험은 DPPH(1,1-diphenyl-2-picryl hydrazyl, Sigma Chemical Co., St. Louis, MO, USA)에 의한 전자공여능(electron donating ability, $\mathrm{EDA}$ )을 측정하였다 (8). 즉, $0.2 \mathrm{mM}$ 의 $\mathrm{DPPH}$ 용액 $0.8 \mathrm{~mL}$ 에 식물추출물 시료 $0.2 \mathrm{~mL}$ 를 첨가하여 혼합한 다음 실온에서 30 분간 반응시킨 후 $517 \mathrm{~nm}$ 에서 흡광도를 측정하였다. 항산화력은 [1-(시료 첨가구의 흡광도/무첨가구의 흡광도) $\times 100$ 의 계산식에 의 해 전자공여능(\%)을 구하였으며, 대조구는 시료 대신 메탄 올을 첨가하였고, positive control로 L-ascorbic acid를 사용 하였다. 각 처리농도에서의 결과 수치로 $50 \%$ 저해 농도 $\left(\mathrm{ID}_{50}\right)$ 을 계산하여 $\mathrm{DPPH}$ 소거 활성 정도를 표현하였다.

\section{Tyrosinase 저해활성측정}

Melanin 합성 주요 단계에 관여하는 tyrosinase 저해활성 측정은 효소 작용 결과 형성되는 DL-B-3,4-dihydroxyphenyl alanine(DOPA) chrome을 비색법에 의해 측정하는 Masamoto 등의 방법(9)을 변형하여 측정하였다. 기질로서 $5 \mathrm{mM}$ DL-DOPA 용액 $0.2 \mathrm{~mL}, 0.1 \mathrm{M}$ 인산완충용액(pH 6.8) 0.2 $\mathrm{mL}$ 및 시료용액 $0.5 \mathrm{~mL}$ 의 혼합액에 mushroom tyrosinase (Sigma, USA, $250 \mathrm{unit} / \mathrm{mL}$ ) $0.1 \mathrm{~mL}$ 을 첨가하여 $37^{\circ} \mathrm{C}$ 에서 10 분간 반응시킨 다음 $475 \mathrm{~nm}$ 파장에서 흡광도를 측정하고 아래 식에 따라 tyrosinase 저해활성을 산출하였다. 각 처리 농도에서의 결과 수치로 $50 \%$ 저해 농도( $\left(\mathrm{ID}_{50}\right)$ 을 계산하여 tyrosinase 저해 활성 정도를 표현하였다.

\section{시료첨가구의 흡광도}

Tyrosinase 저해 활성 $(\%)=1-\begin{gathered}\text { 시료첨가구의 흡광도 } \\ \text { 조구의 흡광도 }\end{gathered} \times 100$

멜라닌 생성 저해 측정

멜라닌 정량은 Hosoi 등의 방법(10)을 변형하여 사용하 였다. 24 well plate에 $2 \times 10^{4}$ cells/well로 멜라노마 세포 (murine melanoma $\mathrm{B} 16 \mathrm{~F} 10$ )를 분주하였고, $100 \mu \mathrm{M}$ 3-isobutyl-1-methylxanthine(IBMX)으로 멜라닌 생성을 유 도한 후, 상기 세포독성 실험에서 관찰된 루꼴라 추출물시 료 농도를 처리하고 48 시간 동안 $37^{\circ} \mathrm{C} \mathrm{CO}_{2}$ 배양기에서 배양 하였다. 세포를 수집하여 세포수를 측정하고, $1,200 \mathrm{rpm}$ 에 서 5 분간 원심 분리하여 침전한 후, $1 \mathrm{~mL}$ homogenization buffer(50 mM sodium phosphate $\mathrm{pH} 6.5,1 \%$ Triton $\mathrm{X}-100$, $2 \mathrm{mM}$ PMSF)로 용해시켰다. 여기서 얻은 pellet에 $1 \mathrm{~N}$ $\mathrm{NaOH}(10 \% \mathrm{DMSO}) 200 \mu \mathrm{L}$ 를 첨가하고 vortex 후 $405 \mathrm{~nm}$ 에 서 흡광도값을 측정하였다. 추출물을 처리하지 않은 시료 군을 대조군으로 하고 미백제로 알려진 합성물질인 arbutin 을 표준시료로 사용하였으며 결과는 $\%$ 로 환산하였다. 각 처리농도에서의 결과 수치로 $50 \%$ 멜라닌 생성 저해 농도 
(ID50)을 계산하여 멜라닌 생성 저해 활성을 표현하였다.

\section{Western blot 분석}

루꼴라 추출물에 의한 tyrosinase 단백질 발현을 분석하 기 위하여 western blot을 시행하였다. 멜라노마 세포 (murine melanoma B16F10)를 alpha-Melanocyte Stimulating Hormone(a-MSH)첨가로 멜라닌 생성을 유도한 후, 상기 세포독성 실험에서 관찰된 추출물시료 농도로 처리하고 48 시간 동안 $37^{\circ} \mathrm{C} \mathrm{CO}_{2}$ 배양기에서 배양하였다. 배양된 세 포를 수확하여 PBS로 두 번 세척한 후, RIPA buffer에서 용해시키고 얼음에서 1 시간 동안 정치시켰다. 처리된 세포 용해물을 $4{ }^{\circ} \mathrm{C} 15,000 \mathrm{rpm}$ 에서 20 분간 원심분리하고, 획득한 상등액은 분석을 위해 $-70^{\circ} \mathrm{C}$ 에서 보관하였다. 단백질 농도 는 protein assay kit(Bio-Rad, Hercules, CA, USA)를 사용하 여 측정하였다. 각 $20 \mu \mathrm{g}$ 단백질량에 해당되는 시료를 $10 \%$ SDS-PAGE에서 전기영동하여 분리 한 후, polyvinylidene fluoride(PVDF) membrane에 옮겨 주었다. Membrane을 상 온에서 1시간 동안 blocking buffer(5\% skim milk in TBST) 에서 처리한 후 1차 항체(mouse anti-tyrosinase: 1:200, Abcam, Cambridge, $\mathrm{UK}$ )를 3 시간 동안 상온에서 처리하였 다. 이후 10 분 간격으로 TBST로 5 회 세척하고 2 차 항체 (rabbit anti-mouse IgG-HRP: 1:5000, Santa Cruz Biotechnology, Carlsbad, CA, USA)로 1시간 동안 반응시켰다. 이후 10 분 간격으로 TBST로 5회 세척하고 enhanced chemiluminescence (ECL) western blotting detection kit(Amersham Pharmacia Biotech, Piscataway, NJ, USA)로 검출하였다. 단백질밴드 는 Photo- Image System(Molecular Dynamics, Uppsala, Sweden)기기를 사용하여 정량하였다.

\section{통계처리}

모든 실험은 독립적으로 3 회 반복 시행하고 실험결과는 평균 \pm 표준편차로 표기하였으며, 통계적 유의성은 Student's $\mathrm{t}$-test로 하였으며 $\mathrm{p}<0.05$ 수준일 때 통계적으로 유의하다고 판단하였다.

\section{결과 및 고찰}

\section{루꼴라 추출물의 세포독성시험}

멜라노마 세포에 루꼴라 추출물(E. sativa extract: ES) $1 \mathrm{mg} / \mathrm{L}, 10 \mathrm{mg} / \mathrm{L}, 100 \mathrm{mg} / \mathrm{L}, 1,000 \mathrm{mg} / \mathrm{L}$ 의 농도로 처리한 후, WST-1 분석법(7)을 이용하여 세포독성을 측정하였다 (Fig. 1). 대조군 대비하여 $1 \mathrm{mg} / \mathrm{L}, 10 \mathrm{mg} / \mathrm{L}, 100 \mathrm{mg} / \mathrm{L}, 1,000$ $\mathrm{mg} / \mathrm{L}$ 의 $\mathrm{ES}$ 농도에서 각각 $0 \%, 1.10 \%, 5.60 \%, 22.30 \%$ 세포 독성을 나타냈으며, $50 \%$ 세포독성을 나타내는 농도( $\left(\mathrm{ID}_{50}\right)$ 는 2,304 mg/L 로 나타났다. 따라서 이후의 실험은 독성이 거의 없는 $100 \mathrm{mg} / \mathrm{L}$ 이하의 농도에서 진행하였으며 멜라닌
생성 억제효과로서 보고된 해양천연물 미역쇠 추출물(11) 의 경우에도 세포독성이 거의 없는 농도가 $100 \mathrm{mg} / \mathrm{L}$ 이하인 것과 비교하였을 때 천연물시료 로서 독성이 없는 안전한 물질로 판단된다.

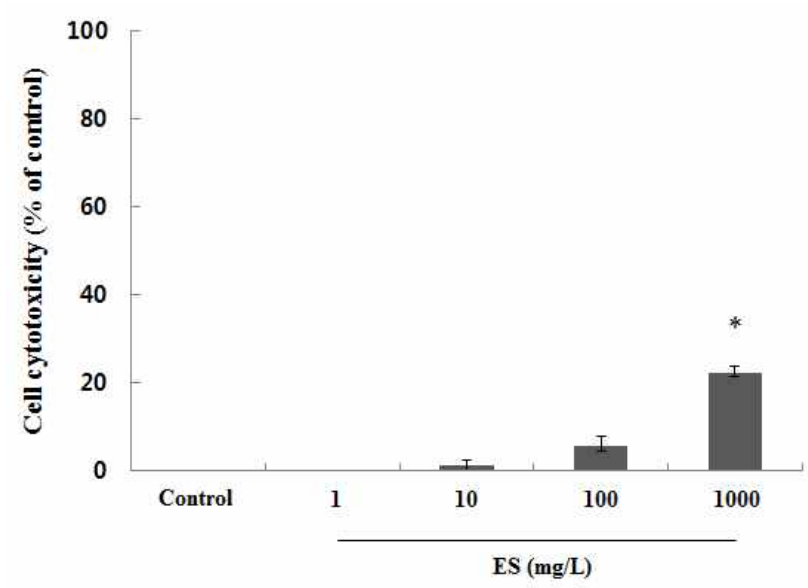

Fig. 1. Cell cytotoxicity of Eruca sativa extract (ES) on murine melanoma B16F10 cells.

Values are presented as mean \pm SEM. Differences were considered statistically significant when ${ }^{*} \mathrm{p}<0.05$.

\section{루꼴라 추출물의 항산화 활성}

루꼴라 추출물에 대해서 DPPH 라디칼 소거 활성법(8)으 로 대조구로 아스코르브산 (ascorbic acid)를 이용하여 항산 화 활성을 측정하였다. 추출물 시료와 대조구 시료를 각각 $10 \mathrm{mg} / \mathrm{L}, 50 \mathrm{mg} / \mathrm{L}, 100 \mathrm{mg} / \mathrm{L}$ 의 농도로 제조하여 $\mathrm{DPPH}$ 소거활성을 측정한 결과 (Fig. 2), ES 농도 $10 \mathrm{mg} / \mathrm{L}, 50 \mathrm{mg} / \mathrm{L}$ 경우 $75.8 \%, 89.7 \%$ 의 소거능 활성을 보였으며 따라서 추출 물 시료의 농도가 증가할수록 라디칼 소거능 활성이 증가하 였다. ES 각각에 대한 같은 시료농도 대조구인 아스코르브 산과 비교 하였을 때는 소거활성이 다소 낮았으나, 100

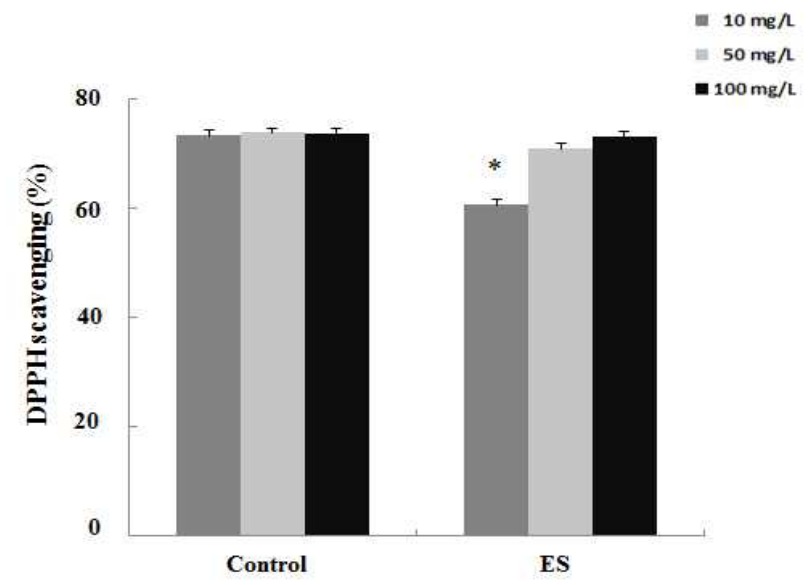

Fig. 2. Antioxidant effects of Eruca sativa extract (ES).

Ascorbic acid was used as a positive control. Values are presented as mean \pm SEM. Differences were considered statistically significant when ${ }^{*} \mathrm{p}<0.05$. 
$\mathrm{mg} / \mathrm{L}$ 의 추출물 농도에서는 대조구와 거의 같은 라디칼 소 거활성을 보였다(94.5\%). 또한, $\mathrm{ES}$ 의 경우, $50 \%$ 라디칼 소 거활성 농도는 $17.60 \mathrm{mg} / \mathrm{L}$ 였으며 대조군 표준시료인 비타 민 C(ascorbic acid)의 경우는 $5.65 \mathrm{mg} / \mathrm{L}$ 였다. 또한, 미백효 과로서 보고된 정공피(12) 및 대나무(13) 추출물의 100 $\mathrm{mg} / \mathrm{L}$ 경우 각각 $40 \%, 50 \%$ 의 소거활성을 보이는 것과 비교 할 때, 항산화 소재로서 더 우수한 루꼴라 추출물의 가능성 을 확인할 수 있다.

\section{루꼴라 추출물의 tyrosinase 저해활성}

Tyrosinase는 구리를 포함한 효소로서 멜라닌 형성에 중 요한 역할을 하고 있다. 이러한 멜라닌 중합체 생합성을 효과적으로 저해하기 위한 tyrosinase 저해활성을 측정하기 위하여 루꼴라 추출물에 대한 mushroom유래의 tyrosinase 저해활성을 관찰하였다(Fig. 3). 추출물시료 $10 \mathrm{mg} / \mathrm{L}, 50$ $\mathrm{mg} / \mathrm{L}, 100 \mathrm{mg} / \mathrm{L}$ 의 경우, 각각 $16.5 \%, 28.4 \%, 40.9 \%$ 의 tyrosinase 저해활성을 나타내었다. 한편, 미백활성의 표준 시료로서 kojic acid $100 \mathrm{mg} / \mathrm{L}$ 의 경우 $60.8 \%$ 의 저해활성을 나타내었다. 또한, $\mathrm{ES}$ 의 경우, $50 \%$ tyrosinase 저해활성 농 도는 $132.54 \mathrm{mg} / \mathrm{L}$ 였으며 대조군 표준시료인 kojic acid의 경우는 $89.13 \mathrm{mg} / \mathrm{L}$ 였다. 루꼴라 추출물시료가 대조군 kojic acid와 비교했을 때 다소 높게 나타났으나 다른 천연소재 중 우수한 미백활성 효과로서 보고된 바(14) 있는 더덕 추출 물 $100 \mathrm{mg} / \mathrm{L}$ 의 경우 $20.0 \%$ tyrosinase 저해활성을 보이는 것과 비교하였을 때, 향후 미백 기능성 소재로서의 활용 가능성이 높다고 생각된다.

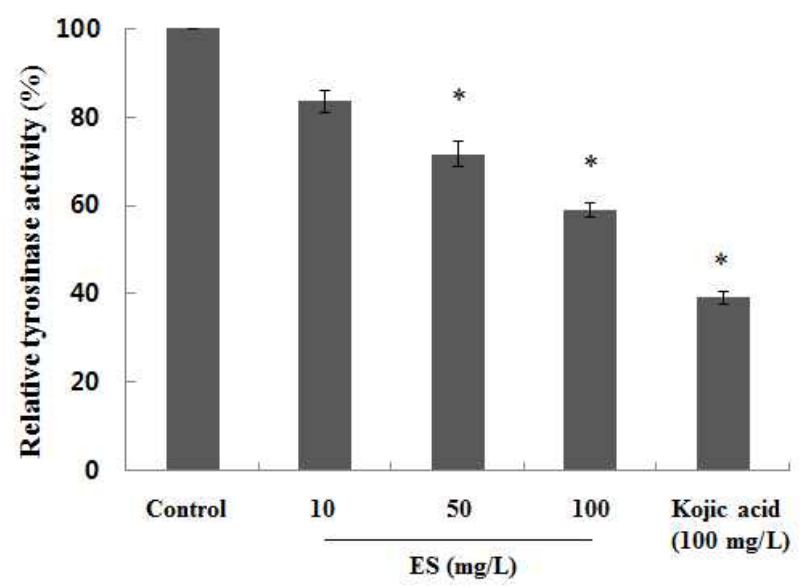

Fig. 3. Inhibitory effect of Eruca sativa extract (ES) on tyrosinase.

The tyrosinase activity assay was performed using mushroom tyrosinase. Values are presented as mean \pm SEM. Differences were considered statistically significant when ${ }^{\star} \mathrm{p}<0.05$.

\section{루꼴라 추출물의 멜라닌 생성 저해활성}

루꼴라 추출물(ES)에 대한 세포독성 실험 측정에서 정한 독성이 없는 농도에서 멜라닌 생성 저해 활성을 측정하였다 (Fig. 4). 대조군 대비하여 $12.5 \mathrm{mg} / \mathrm{L}, 25 \mathrm{mg} / \mathrm{L}, 50 \mathrm{mg} / \mathrm{L}$,
$100 \mathrm{mg} / \mathrm{L}$ 의 $\mathrm{ES}$ 농도에서 각각 $5.56 \%, 15.02 \%, 18.78 \%$, $31.04 \%$ 의 멜라닌 생성 억제 활성을 확인하였다. 또한, $\mathrm{ES}$ 의 경우, $50 \%$ 멜라닌 저해활성 농도는 $158.90 \mathrm{mg} / \mathrm{L}$ 이였으며 또한, 대조군 표준시료로서 tyrosinase 경쟁적 저해제로 작 용한다고 알려져 있는(4) arbutin의 경우는 $100.70 \mathrm{mg} / \mathrm{L}$ 임을 고려하면 멜라닌 생성 저해 활성이 우수함을 의미한다. 즉, 시험재료에 있어서 피부미백효과는 멜라닌 생성 저해에 따른 tyrosinase 저해효과가 나타나야 한다. 본 연구의 루꼴 라 추출물의 경우도 멜라닌 저해 할성이 우수하였으며 이에 따른 tyrosinase 저해활성도 높았다.

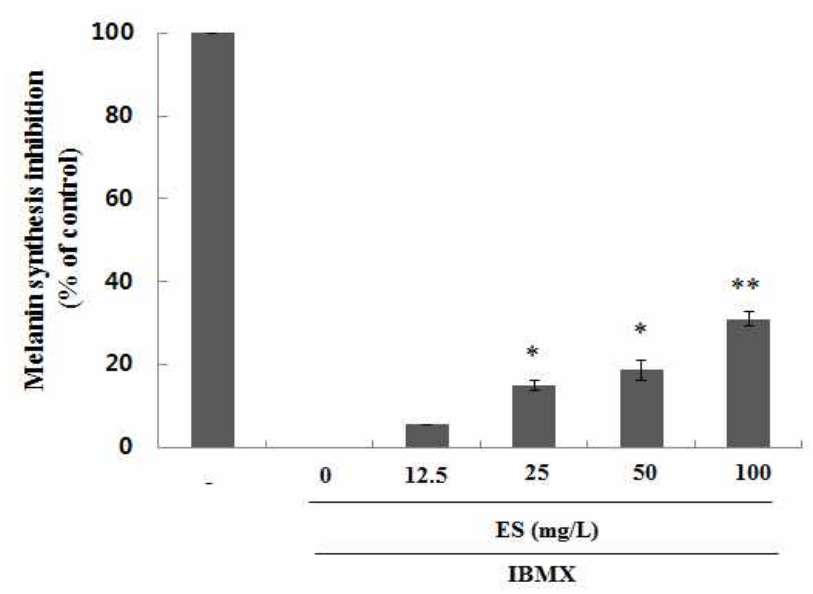

Fig. 4. Anti-melanogenic effects of Eruca sativa extract (ES).

Cells were treated with $100 \mu \mathrm{M} \mathrm{IBMX}$ in the presence or absence of ES, at the indicated concentration, for 2 days.Values are presented as mean \pm SEM. Differences were considered statistically significant when ${ }^{*} \mathrm{p}<0.05,{ }^{*} \mathrm{p}<0.01$.

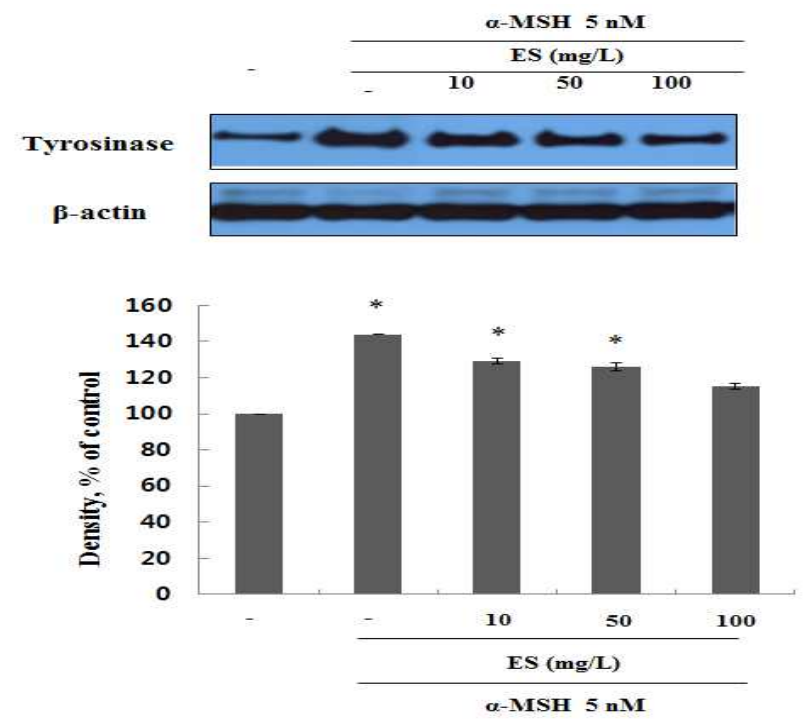

Fig. 5. Effect of Eruca sativa extract (ES) on the expression of tyrosinase.

Western blot analysis was used to identify the expression of tyrosinase. Cells were treated with $5 \mathrm{nM}$ a-MSH in the presence or absence of ES, at the indicated concentration, for 2 days. $\beta$-actin was used as standard. Values were nomalized to $\beta$-actin before calculating changes and presented as mean \pm SEM. Differences were considered statistically significant when ${ }^{*} \mathrm{p}<0.05$. 
루꼴라 추출물의 tyrosinase 발현 억제 효과

루꼴라 추출물(ES)에 의한 tyrosinase 단백질 발현에 미치 는 영향을 독성이 없는 농도에서 측정하였다(Fig. 5). a -MSH 처리로 멜라닌 생성을 유도한 후, a-MSH 와 ES 모두 처리 하지 않은 대조군 대비하여 a-MSH와 함께 각각 무처 리, $10 \mathrm{mg} / \mathrm{L}, 50 \mathrm{mg} / \mathrm{L}, 100 \mathrm{mg} / \mathrm{L}$ 의 $\mathrm{ES}$ 농도에서 각각 $144 \%$, $129 \%, 126 \%, 115 \%$ 로 농도 의존적으로 tyrosinase 발현이 억제되었으며, $100 \mathrm{mg} / \mathrm{L} \mathrm{ES}$ 농도에서 대조군과 통계적으 로 차이가 없이 저하되는 것을 확인하였다. 따라서 루꼴라 추출물의 경우, 직접적인 tyrosinase 활성저해 및 발현억제 효과에 의한 기작으로 멜라닌 생성이 억제된 것으로 사료 된다.

\section{요 약}

본 연구에서 루꼴라(E. sativa)에 대한 다양한 생리활성을 조사하여 기능성소재 응용가능성을 검토하였다. 루꼴라 추 출물은 멜라노마 세포에 대하여 낮은 세포독성을 나타냈 다. 세포독성이 거의 없는 농도에서 루꼴라 추출물 처리 시 항산화 활성 $\left(\mathrm{ID}_{50}, 17.60 \mathrm{mg} / \mathrm{L}\right)$ 이 매우 우수하게 나타났 으며 루꼴라 추출물 처리시 높은 tyrosinase 활성저해( $\mathrm{ID}_{50}$, $132.54 \mathrm{mg} / \mathrm{L})$ 및 멜라닌 함량 저하(ID $\left.{ }_{50}, 158.90 \mathrm{mg} / \mathrm{L}\right)$ 를 보여주었다. 또한, 루꼴라 추출물 농도 의존적으로 tyrosinase 발현이 억제되었으며, 이는 루꼴라 추출물이 직 접적인 tyrosinase 활성저해 및 세포 내 tyrosinase 발현을 억제시킴으로서 멜라닌 합성을 저해하는 것으로 판단된다. 이와 같은 결과로 미루어 볼 때 루꼴라 추출물은 피부미백 소재 등 피부개선 효과를 지닌 기능성 화장품에 활용하기 위한 매우 효과적인 재료가 될 수 있다고 판단되며 향후 주름개선 효과 등 추가적인 실험을 통하여 화장품 소재 개발 응용 가능성을 타진할 것이다.

\section{감사의 글}

본 연구는 2014년도 교육부와 한국연구재단(NRF)의 이 공분야기초연구지원사업의 지원(2014R1A1A2057651)에 의해 수행되었습니다.

\section{References}

1. Sohn ES, Kim SW, Kang JS, Lee SP (2004) Technology trend patent information analysis of cosmetic materials derived from natural products. Appl Chem, 8, 466-469 2. Hill HZ, Li W, Xin P, Michell DL (1997) Melanin: a two edged sword?. Pigment Cell Res, 10, 158-161

3. Kobayashi T, Urabe K, Winder AJ, Jimenez-Cervantes C, Imokawa G, Brewington T, Solano F, Garcia-Borron JC, Hearing VJ (1994) Tyrosinase related protein-1 (TRP-1) function as a DHICA oxidase in melanin biosynthesis. EMBO J, 3, 5818-5825

4. Briganti S, Camera E, Picardo M (2003) Chemical and instrumental approaches to treat hyperpigmentation. Pigment Cell Res, 16, 101-110

5. Lamy E, Schröder J, Paulus S, Brenk P, Stahl T, Mersch-Sundermann V (2008) Antigenotoxic properties of Eruca sativa (rocket plant), erucin and erysolin in human hepatoma (HepG2) cells towards benzo(a)pyrene and their mode of action. Food Chem Toxicol, 46, 2415-2421

6. Sarwar Alam M, Kaur G, Jabbar Z, Javed K, Athar M (2007) Eruca sativa seeds possess antioxidant activity and exert a protective effect on mercuric chloride induced renal toxicity. Food Chem Toxicol, 45, 910-920

7. Ranke J, Mölter K, Stock F, Bottin-Weber U, Poczobutt J, Hoffmann J, Ondruschka B, Filser J, Jastorff B (2004) Biological effects of imidazolium ionic liquids with varying chain lengths in acute Vibrio fischeri and WST-1 cell viability assays. Ecotoxicol Environ Saf, 58, 396-404

8. Miliauskas G, Venskutonis PR, van Beek TA (2004) Screening of radical scavenging activity of some medicinal and aromatic plant extracts. Food Chem, 85, 231-237

9. Masamoto Y, Ando H, Murata Y, Shimoishi Y, Tada M, Takahata K (2003) Mushroom tyrosinase inhibitory activity of esculetin isolated from seeds of Euphorbia lathyris L. Biosci Biotechnol Biochem, 67, 631-634

10. Hosoi J, Abe E, Suda T, Kuroki T (1985) Regulation of melanin synthesis of B16 mouse melanoma cells by 1 alpha, 25-dihydroxyvitamin D3 and retinoic acid. Cancer Res, 45, 1474-1478

11. Jeon YS, Jung YJ, Youm JK, Kim YK, Kim SN (2013) Inhibitory effect of Endarachne binghamiae extract on melanin synthesis. Korean J Plant Res, 26, 526-532

12. Kim TH, You JK, Kim JM, Baek JM, Kim HS, Park JH, Choe M (2010) Antioxidant and whitening effects of Sorbus commixta HEDL cortex extract. J Korean Soc Food Sci Nutr, 39, 1418-1424

13. Song HS, Moon HJ, Park BE, Choi BS, Lee DJ, Lee JY, Kim CJ, Sim SS (2007) Anti-oxidant activity and whitening activity of bamboo extracts. J Pharm Soc, 51, 500-507 
14. Kim JS, Kim JW, Kwon HS, Lim HW, Lee HY (2013) Screening of skin whitening activity of Codonopsis lanceolata extract by complex streaming process. Korean J Med Crop Sci, 21, 54-60 